\title{
The effect of a summer flood on the density of caddisfly (Trichoptera) in the middle reaches of the Shinano River, Japan
}

\author{
GORO KIMURA, EISO INOUE \& KIMIO HIRABAYASHI* \\ Division of Applied Biology, Faculty of Textile Science \& Technology, Shinshu University, 3-15-1 Tokida, Ueda, Nagano, 386-8567, \\ Japan \\ *Corresponding author: E-mail: kimio@shinshu-u.ac.jp
}

\begin{abstract}
We investigated the response of caddisfly species assemblages in the middle reaches of the Shinano River to a flood that occurred in mid July 2006. Prior to the flood (on Day -22) the population density of total benthic caddisflies was $8,266.7 \pm 2,392.1$ individuals $\mathrm{m}^{-2}$. After the flood, by Day 11, the population density had decreased to $55.6 \pm 55.6$ individuals $\mathrm{m}^{-2}$. By Day 65 , the density of caddis species had recovered to nearly the same level as that recorded before the flood, particularly in the case of Hydropsyche orientalis Martynov, the most abundant benthic species. By Day 65 the larvae of this species had reached pre-flood levels. On Day 40 it was noted that the larval population was dominated by final instars, but by Day 65 early instar larvae were dominant and downstream drift consisted mainly of second instars. Moreover, $H$. orientalis adults were constantly collected during the study period and the abundance of adults increased after Day 50. These results suggested that drift and reproduction were the main recolonization mechanisms that contributed to the rapid recovery of benthic caddisfly after the flood.
\end{abstract}

Key words: adult caddisfly, disturbance, drift, Hydropsyche orientalis, larval stage, recovery

\section{Introduction}

Succession of benthic macroinvertebrate communities following a physical disturbance has attracted considerable interest (reviewed by Mackay 1992) and is important for understanding the population dynamics of macroinvertebrate communities in lotic ecosystems (e.g., Fisher 1983, Sheldon 1984, Resh et al. 1988). In streams and rivers, floods are an important organizing factor that affects benthic macroinvertebrate communities and can result in the creation of open patches in stream beds (Resh et al. 1988, Townsend 1989, Lake 2000). A number of field experimental studies have been undertaken to describe colonizing patterns of benthic macroinvertebrates after small-scale manipulation of habitats, such as the introduction of new substrates (reviewed by Hayashi 1991, Mackay 1992). Because of difficulties associated with organizing large-scale manipulation experiments, details of natural regimes of flooding disturbance in streams and rivers are not well known. Investigating the population dynamics of macroinvertebrate communities during flood events represents a 'natural experiment' that can be undertaken to accomplish such studies.

Because river basins have often suffered from flood disasters, many streams and rivers in Japan have been modified for the purpose of flood control (Tamai et al. 1993, Tamai et al. 2000). After the new River Law was established in 1997, conservation and restoration of river environments were added to the objectives of Japanese river management. However, management methods are still 
being developed. For this reason, the demand for knowledge about the responses of lotic ecosystems to natural and artificial disturbances has become increasingly important.

Trichoptera (caddisflies) represent one of the largest groups of macroinvertebrates found in lotic ecosystems. Caddisfly larvae are usually abundant in lotic ecosystems (Wiggins 1996, Tanida et al. 2005, Morse \& Holzenthal 2008, Wiggins \& Currie 2008) and are important secondary producers (Mackay \& Wiggins 1979). An exceptionally strong flood occurred in the Shinano River basin in mid July 2006, following heavy rains. The objective of our study was to examine the response of caddisflies to this flood that had caused widespread disturbance to the environment in the middle reaches of the Shinano River.

\section{Material and methods}

\section{Study site}

The Shinano River is the longest river in Japan (length $367 \mathrm{~km}$; drainage area 11,900 $\mathrm{km}^{2}$ ). It runs through Nagano and Niigata Prefectures and flows north to the Japan Sea. The study site $\left(36^{\circ} 23^{\prime} \mathrm{N}, 138^{\circ} 15^{\prime} \mathrm{E} ; 450 \mathrm{~m}\right.$ above sea level) is in a 5th order section of the Shinano River, located $258 \mathrm{~km}$ upstream from the river mouth (Fig. 1). The riverine environment in this region - which consists of 'unit structures' of a natural river system, i.e., scour pools, riffles and runs - has been generally well preserved. The riverbed substrate of the river is largely composed of loose cobbles and boulders (approximately from 10 to $30 \mathrm{~cm}$ ), and the channel width is about $25 \mathrm{~m}$. Some artificial structures that protect the riverbank from erosion have been constructed along the river.

\section{Collecting caddisflies}

During 2006, benthic and drift samples of caddisfly were collected on a monthly basis: on June 27 (22 days before the flood: Day -22), July 30 (Day 11), August 28 (Day 40), and September 22 (Day 65). A Surber sampler $\left(30 \times 30 \mathrm{~cm}^{2}, 450 \mu \mathrm{m}\right.$ mesh) was used to collect both benthic and drift samples. In the case of benthic samples, all the materials and organisms attached on the substrates were scraped into the net. Drift samples were collected by means of directing the opening against the water flow for 3 minutes. Both types of the samples were replicated 3 times in order to provide quantitative data for statistical analysis. The residues in the net were carefully put into a polyethylene bag and fixed immediately with $10 \%$ formalin. Qualitative benthic samples were also collected for larval rearing so as to obtain adults for identification to species level.

Following the recommendations outlined by Kimura et al. (2008), we decided to collect adult caddisflies on a daily basis from Day -22 to Day 65 by means of light trapping. A vending machine that had been equipped with three 32-W daylight fluorescent lamps was used for this purpose. The light trap was set on a causeway alongside the river, approximately $150 \mathrm{~m}$ from the water's edge (Fig. 1).

All the caddisflies in the light trap samples were identified to species, following the taxonomic keys of Wiggins (1996) and Tanida et al. (2005) and a binocular dissecting microscope which was also used to count specimen numbers. In the case of immature that could be identified only to genus level, the species names of the adults of the same genus that were obtained through larval rearing was used in this study. In addition, each instar of Hydropsyche orientalis Martynov larvae was determined by estimating head width and morphological features, as described by Tanida (1980). 


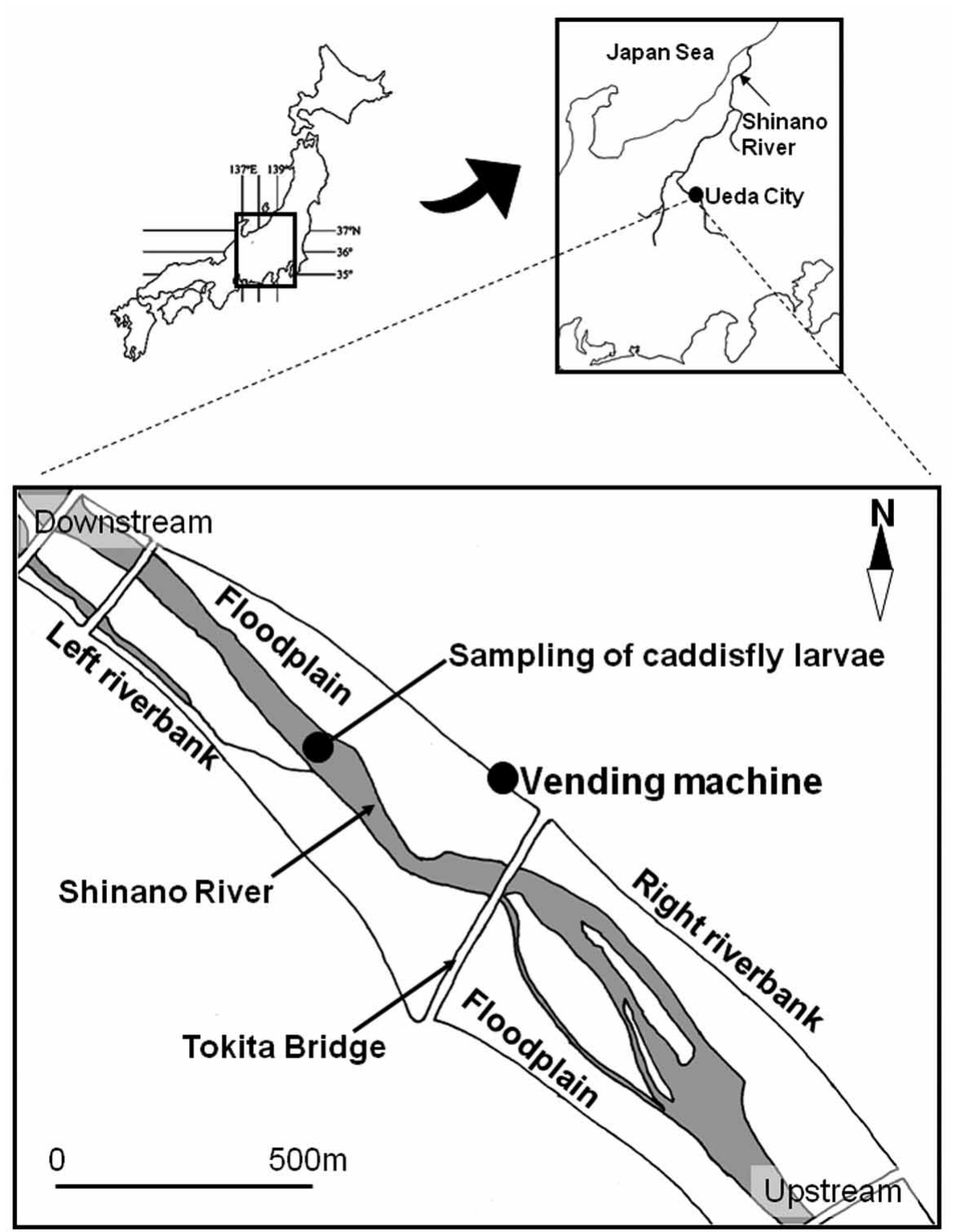

FIGURE 1. Map of the middle reaches of the Shinano River, with locations of sampling sites.

\section{Environmental measurements and data analyses}

We measured physicochemical conditions on each sampling occasion using portable meters. The parameters included dissolved oxygen concentration (DO-24P; DKK-TOA Corp., Tokyo Japan), electric conductivity, pH (WM-22EP; DKK-TOA Corp., Tokyo Japan) and water temperature. Current velocity at the study sites was also measured on each sampling occasion using portable meters (VE-10; Kenek Co. Ltd., Tokyo, Japan). Water depth was measured for the purpose of calculating densities of drifting individuals per unit discharge. Water level and volume data were obtained from the Ministry of Land, Infrastructure and Transport, Japan (2006).

The number of caddisfly species on each sampling occasion was expressed as the total number collected in the 3 sampling replications. Shannon-Wiener's diversity index ( $\left.H^{\prime}\right)$ was calculated using the total abundance of each caddisfly species collected on each sampling occasion.

Statistical tests were accomplished using SPSS version 11.5.1J for Windows (SPSS Japan Inc., Tokyo, Japan). 


\section{Results and discussion}

Each physicochemical condition was similar before and after the flood at the site (Table 1). Each parameter was relatively constant on each sampling occasion. An excessively strong flood that recorded a $2.94 \mathrm{~m}$ peak above the daily mean water level, occurred on July 19, 2006. The maximum water volume reached $2897.99 \mathrm{~m}^{3} \mathrm{~s}^{-1}$ at the Kuisege Water Observatory $\left(36^{\circ} 31^{\prime} \mathrm{N}, 138^{\circ} 06^{\prime} \mathrm{E}\right)$ which was located about $23 \mathrm{~km}$ distance from the sampling site. The daily mean water level established after Day 11 (Fig. 2) but small floods occurred again through October 6 into 7, 2006 (with maximum levels and water volume of $1.06 \mathrm{~m}^{3} \mathrm{~s}^{-1}$ and $904.86 \mathrm{~m}^{3} \mathrm{~s}^{-1}$, respectively) and this had a major effect on caddisfly larvae. As a result, we had to terminate our benthic and drift investigation on Day 65 .

TABLE 1. Environmental measurements before and after the flood in the middle reaches of the Shinano River.

\begin{tabular}{lcccccc}
\hline & \multicolumn{3}{c}{ Before the flood } & & \multicolumn{2}{c}{ After the flood } \\
\cline { 2 - 3 } \cline { 5 - 7 } & $n$ & mean \pm SD & & $n$ & mean \pm SD \\
\hline Water temperature $\left(\mathrm{C}^{\circ}\right)$ & 1 & 22.4 & & 3 & $23.5 \pm 1.7$ \\
pH & 1 & 8.60 & & & 3 & $8.27 \pm 0.64$ \\
Electric conductivity $\left(\mathrm{mS} \mathrm{m}^{-1}\right)$ & 1 & 17.84 & & & 3 & $16.36 \pm 1.63$ \\
Dissolved oxgen $\left(\mathrm{mg} \mathrm{L}^{-1}\right)$ & 1 & 9.89 & & & 3 & $9.74 \pm 1.5$ \\
Water depth $(\mathrm{cm})$ & 3 & $17.3 \pm 4.5$ & & 9 & $22.6 \pm 3.6$ \\
Current velocity $\left(\mathrm{cm} \mathrm{s}^{-1}\right)$ & 3 & $134.3 \pm 2.0$ & & 9 & $107.5 \pm 9.1$ \\
\hline
\end{tabular}

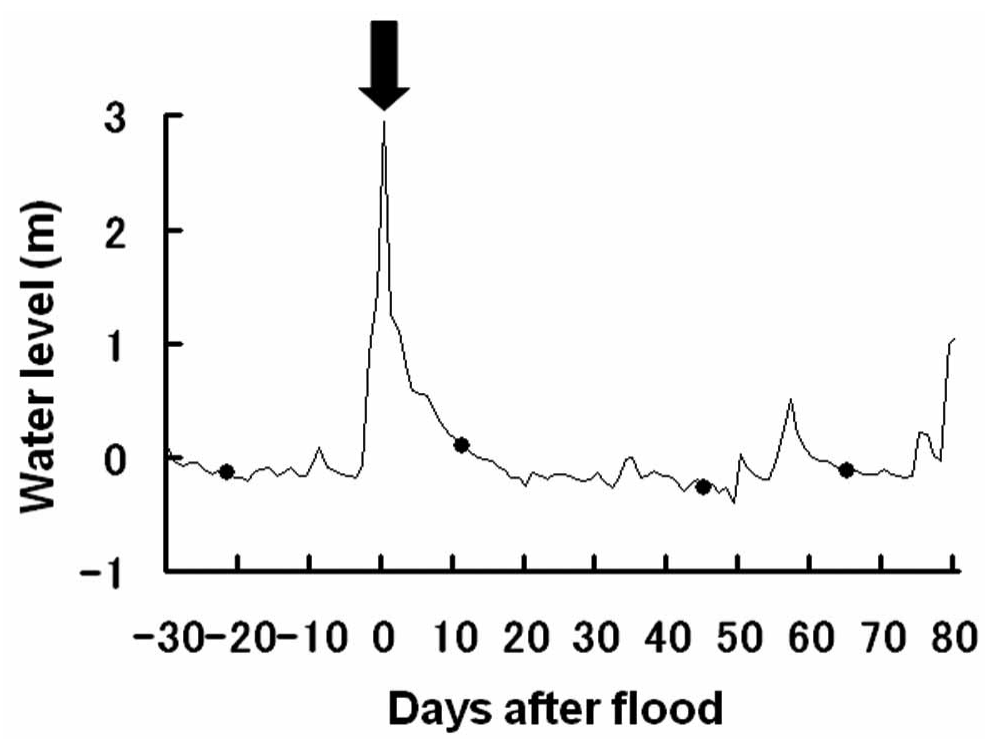

FIGURE 2. Daily mean water level during the study period, provided by the Ministry of Land, Infrastructure and Transport, Japan. Solid circles indicate the dates of benthic and drift sampling investigation. Arrow shows the peak water level of the flood.

A total of 9 caddisfly species belonging to 5 families were collected at the study site (Table 2). Before the flood, H. orientalis was the most abundant species of benthic caddisfly, accounting for $71.1 \%$ of the mean density during the study, followed by Stenopsyche marmorata Navás (13.6\%) and Cheumatopsyche infascia Martynov (5.9\%). The 3 most abundant species after the flood were $H$. orientalis (56.6\%), C. infascia (15.0\%) and C. brevilineata (Iwata) (11.6\%). Each of 7 species 
collected at the study site was collected both before and after the flood, whereas Glossosoma ussuricum (Martynov), and C. brevilineata were collected only after the flood. These species may have been introduced from tributaries. Unfortunately, the details are unclear because we did not collected trichopteran larvae from tributaries. The number of caddisfly species and diversity index $\left(H^{\prime}\right)$ were relatively constant for each sampling occasion (Fig. 3). After the flood, the number of species gradually increased from 6 to 9. Finally, on Day 65, the number exceeded that recorded before the flood. The diversity index ( $H^{\prime}$ ) was, however, the highest (at 2.21) on Day 11 and then decreased gradually until Day 65. The total density of caddisflies at the site decreased dramatically from Day $-22\left(8,266.7 \pm 2,392.1\right.$ individuals $\left.\mathrm{m}^{-2}\right)$ to Day $11\left(55.6 \pm 55.6\right.$ individuals $\left.\mathrm{m}^{-2}\right)$ and then increased gradually after the flood (Fig. 3). Finally, on Day 65, total caddisfly density at the site was not significantly different $\left(4,988.9 \pm 1,291.1\right.$ individuals $\left.\mathrm{m}^{-2}\right)$ from that recorded before the flood (Mann-Whitney $U$ test, $p=0.1$ ). Comparison of density and community structure suggests a connection between diversity and equitability with the number of species in the river. Flood affects the caddisfly community and gives the less abundant species a chance to remain as a stable component.

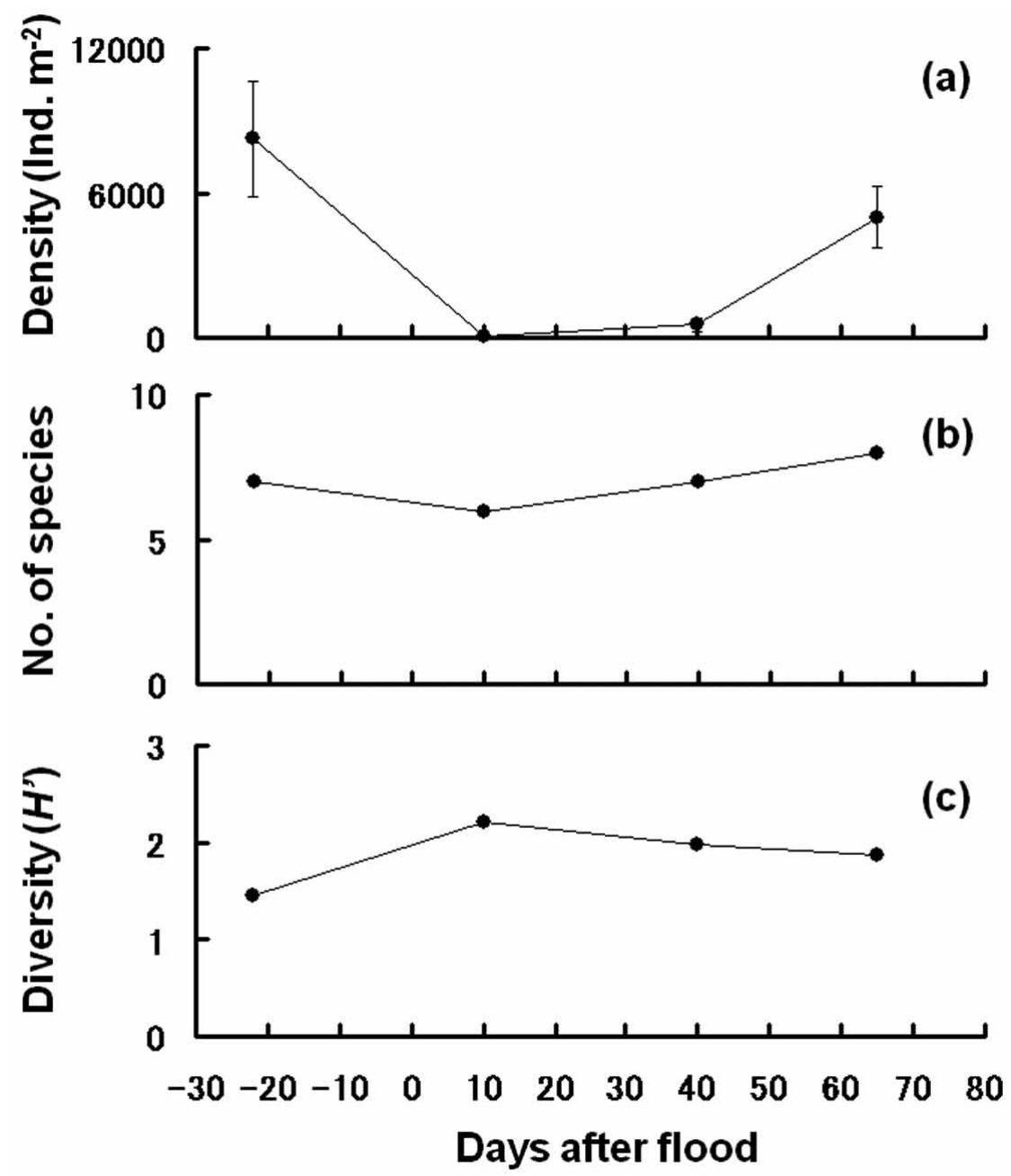

FIGURE 3. Changes in (a) total caddisfly density, (b) number of species, and (c) Shannon-Wiener's diversity index $\left(H^{\prime}\right)$ during the study period.

The mean benthic population density of $H$. orientalis at the site before the flood was $5,874.1 \pm$ 2,014.8 individuals $\mathrm{m}^{-2}$ (Fig. 4). Population density at the site on Day 11 was extremely low (14.8 \pm 17.0 individuals $\mathrm{m}^{-2}$ ) and increased gradually. By Day 65, the density of $H$. orientalis at the site 
reached a population level $\left(2,877.8 \pm 1,022.2\right.$ individuals $\left.\mathrm{m}^{-2}\right)$ not significantly different from that recorded before the flood (Mann-Whitney $U$ test, $p=0.2$ ). Second and 3rd instars of H. orientalis larvae from benthic samples reached a high density on Day 65, in spite of the dominance $(66.7 \%)$ of final instar larvae on Day 40. The mean density of $H$. orientalis larval drift fluctuated within low ranges $\left(0.0-0.1\right.$ individuals $\left.\mathrm{m}^{-3}\right)$ on each sampling occasion (Fig 4c). Population densities of drift at the sites decreased for some time after the flood and no drift (i.e., 0.0 individuals $\mathrm{m}^{-3}$ ) was recorded on Day 40. On Day 65 drift once again was back to $0.10 \pm 0.12$ individuals $\mathrm{m}^{-3}$. Second instar $H$. orientalis larvae were dominant in the downstream drift (75.0\%) on Day 65. Hydropsyche orientalis adults were collected throughout the study period. A total of $87 \mathrm{H}$. orientalis adults were collected between Day -22 and Day 65. Their abundance increased after Day 50, accounting for 77.0\% (67 individuals) of the total adults. Daily mean abundance between Day -22 and Day 49 was $0.27 \pm 0.57$ individuals. On the other hand, daily mean abundance between Day 50 and Day 65 was $4.21 \pm 4.53$ individuals. Daily mean abundance was significantly different before and after Day 50 (MannWhitney $U$ test, $p<0.001)$.

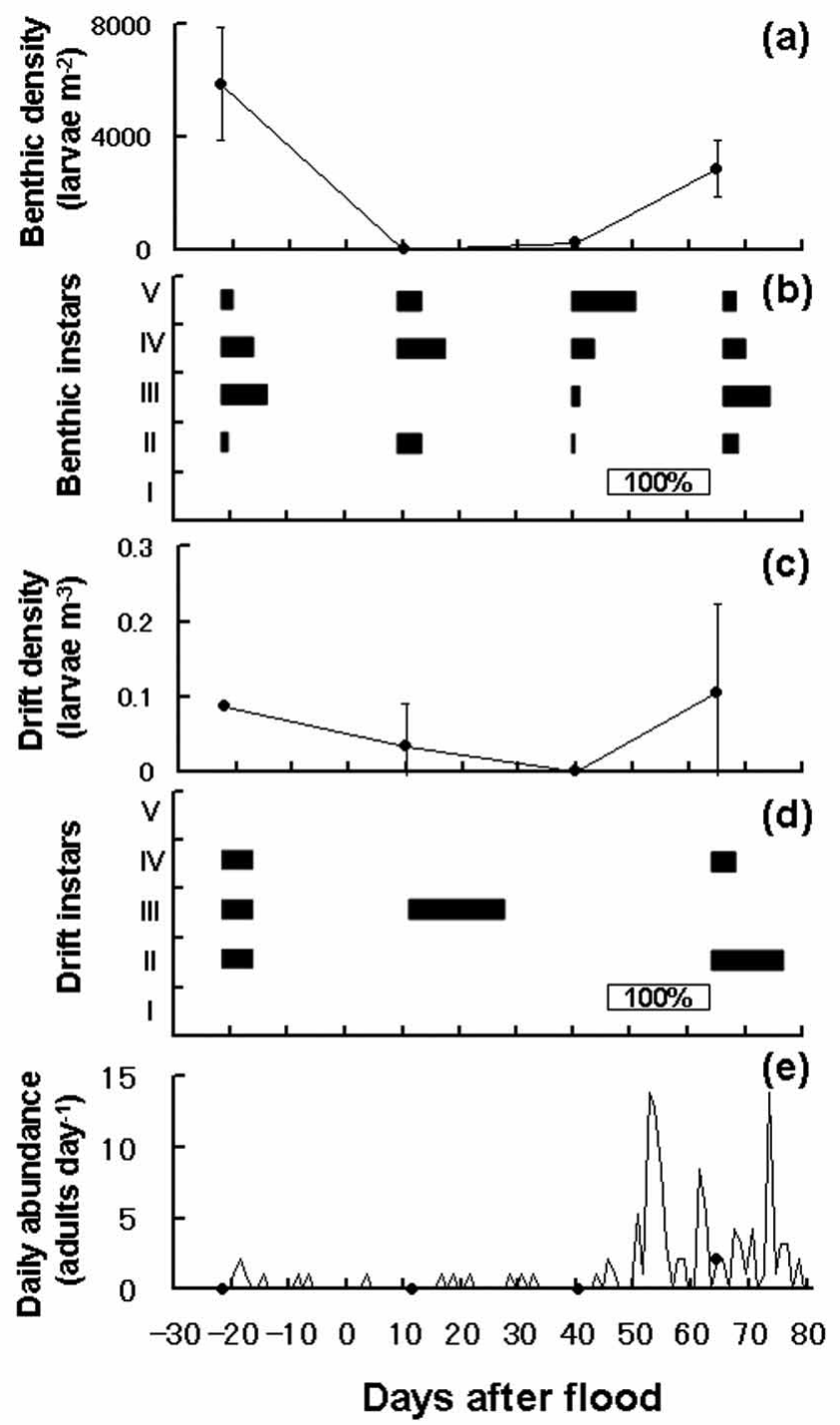

FIGURE 4. Abundance of Hydropsyche orientalis at the sampling sites during the study period; showing (a) benthic density, (b) instars of benthic larvae, (c) drift density, (d) instars of drift larvae, and (e) adults. Solid circles indicate the dates of benthic and drift sampling investigation. The size of black bars indicates the percent of each instar of $H$. orientalis larvae each sampling period. 


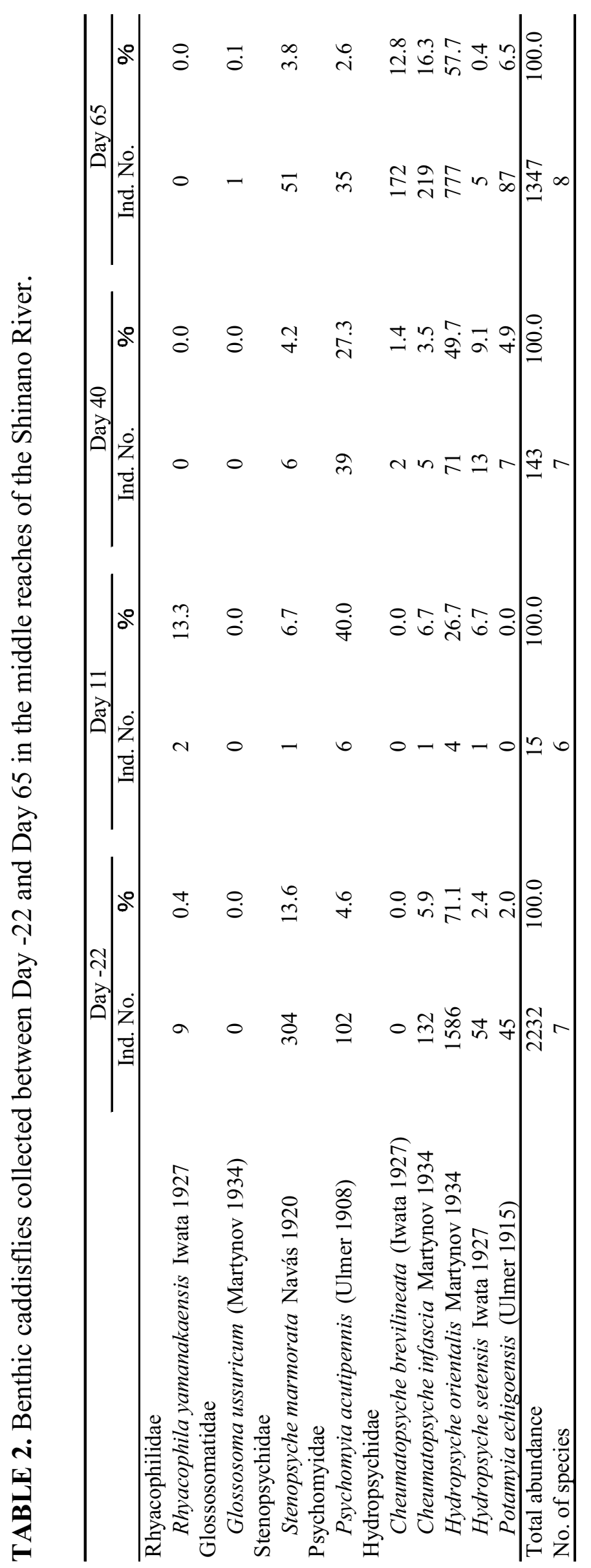


Recovery of benthic macroinvertebrates after disturbance depends primarily on oviposition by adults or drift from upstream areas (Niemi et al. 1990, Wallace 1990, Mackay 1992). In our study, fluctuations in the densities of both benthic and drifting caddisflies followed similar trends throughout the study period. In addition, when the abundance of early instar $H$. orientalis larvae in the benthic samples was high, the densities of both benthic and drifting $H$. orientalis increased. Early instar hydropsychid larvae are more likely to drift than later instars (Shibata 1975, Bergey \& Ward 1989). Early instar trichopteran larvae exhibit a neutral phototaxis (Fjellheim 1980, Coutant 1982). We also collected drifting early instar larvae in the daytime. However, we did not investigate larval drift in the night. By Day 65, the density of $H$. orientalis was a similar magnitude before the flood. In addition, early instar larvae from benthic samples reached a high density on Day 65. From 2nd instar and later, rhyacophilid larvae become increasingly night-active, with a culmination in the last instar, which was highly night active (Fjellheim 1980). These facts suggest that drift levels of mature instars may be negligible for dispersal mechanism after summer flood. High drift levels of early instars may be a dispersal mechanism for individuals of newly-hatched cohorts (Elwood \& Cushman 1975). In the present study, $H$. orientalis adults were collected both before and after the flood. Lytle and Poff (2004) reported that, for some aquatic insects, life-history adaptations include the timing of reproduction, emergence into an aerial adult stage, and the ability to avoid mortality by escaping floods. These authors also suggested that life-history adaptations enable rapid recovery after floods. For the reasons mentioned above, high rate of dispersal of early-instar caddisfly larvae, which enables survivors to reach new sites, was probably the major source of colonization of benthic caddisflies after the summer flood. The present study suggest that the life-history of $H$. orientalis has adapted to survive through extensive flooding events.

Hydropsyche orientalis is a widely-distributed and very common species in Japan (Tanida 1986, Tanida et al. 2005). Further research on this species should be undertaken to improve understanding of succession in benthic communities following physical disturbance in streams and rivers. Increased knowledge of population dynamics and macroinvertebrate communities in lotic ecosystems would also assist in designing future aquatic habitat modification schemes.

\section{Acknowledgements}

We would like to thank Mr. Masaaki Takeda, Mr. Keisuke Masada and Mr. Daisuke Toyoda and colleagues at Division of Applied Biology, Faculty of Textile Science and Technology, Shinshu University for their generous support. Many thanks to Ms. Irene Joy de Moor for the linguistic corrections of the manuscript. We thank 2 reviewers for constructive comments that improved the manuscript. This work was supported by River Ecology Research Group of Japan (Chikuma River Group) and Grant-in-Aid for Global COE Program by the Ministry of Education, Culture, Sports, Science and Technology.

\section{References}

Bergey, E.A. \& Ward, J.V. (1989) Upstream-downstream movements of aquatic invertebrates in a Rocky Mountain stream. Hydrobiologia, 185, 71-82.

Coutant, C.C. (1982) Positive phototaxis in first instar Hydropsyche cockerelli Banks (Trichoptera). Aquatic Insects, 4, 55-59.

Elwood, J.W. \& Cushman, R.M. (1975) The life history and ecology of Peltoperla maria (Plecoptera: Peltoperlidae) in a small spring-fed stream. Verhandlungen Internationale Vereinigung für theoretische und 
angewandte Limnologie, 19, 3050-3056.

Fisher, S.G. (1983) Succession in streams, In: Barnes, J.R. \& Minshall, G.W. (Eds.), Stream Ecology: Application and testing of General Ecological Theory, Plenum Press, New York, pp. 7-27.

Fjellheim, A. (1980) Differences in drifting of larval stages of Rhyacophila nubila (Trichoptera). Holarctic Ecology, 3, 99-103.

Hayashi, F. (1991) Dynamic relations within and between populations of stream insect communities. Biological Science, 43, 1-13. (in Japanese)

Kimura, G., Inoue, E. \& Hirabayashi, K. (2008) Seasonal abundance of adult caddisfly (Trichoptera) in the middle reaches of the Shinano River in Central Japan. In: Robinson, W.H. \& Bajomi, D. (Eds.), Proceedings of the 6th International Conference on Urban Pests, OOK-Press Korlátolt felelősségü társaság, Budapest, pp. 259-266.

Lake, P.S. (2000) Disturbance, patchiness, and diversity in streams. Journal of the North American Benthological Society, 19, 573-592.

Lytle, D.A. \& Poff, N.L. (2004) Adaptation to natural flow regimes. Trends in Ecology \& Evolution, 19, 94-100.

Mackay, R.J. (1992) Colonization by lotic macroinvertebrates: a review of processes and patterns. Canadian Journal of Fisheries and Aquatic Sciences, 49, 617-628.

Mackay, R.J. \& Wiggins, G.B. (1979) Ecological diversity in Trichoptera. Annual Review of Entomology, 24, 185208.

Ministry of Land, Infrastructure and Transport, Japan (2006). Water Information Systems. Available from http:// www1.river.go.jp (accessed 28 February, 2009). (in Japanese)

Morse, J.C. \& Holzenthal, R.W. (2008) Trichoptera Genera. In: Merritt, R.W., Cummins K.W. \& Berg, M.B. (Eds.), An Introduction to the Aquatic Insects of North America, Fourth Edition. Kendall/Hunt, Iowa, pp. 481553.

Niemi, G.J., Devore, P., Detenebeck, N., Taylor, D., Lima, A. \& Pastor, J. (1990) Overview of case studies on recovery of aquatic systems from disturbance. Environmental Management, 14, 571-587.

Resh, V.H., Brown, A.V., Covich, A.P., Gurtz, M.E., Li, H.W., Minshall, G.W., Reice, S.R., Sheldon, A.B., Wallace, J.B. \& Wissmar, R. (1988) The role of disturbance in stream ecology. Journal of the North American Benthological Society, 7, 433-455.

Sheldon, A.L. (1984) Colonization dynamics of aquatic insects. In: Resh, V.H. \& Rosenberg, D.M. (Eds.), The Ecology of Aquatic Insects, Praeger, New York, pp. 401-429.

Shibata, K. (1975) The ecology and prevention of Hydropsyche ulmeri Tsuda, pestworms in the waterway tunnels of a hydraulic power plant. Privately published, $149 \mathrm{pp}$. (in Japanese)

Tamai, N., Mizuno, N. \& Nakamura, S. (1993) Environmental River Engineering. University of Tokyo Press, Tokyo, 309 pp. (in Japanese)

Tamai, N., Okuda, S. \& Nakamura, S. (2000) Assessing Riverine Environments for Habitat Suitability on the Basis of Natural Potential. University of Tokyo Press, Tokyo, 270 pp. (in Japanese)

Tanida, K. (1980) Life history and distribution of three species of Hydropsyche (Trichoptera: Hydropsychidae) in the River Kibune (Kyoto, central Japan), with particular references to the variations in their life cycles and the relation of larval growth to their density. Japanese Journal of Limnology, 41, 95-111. (in Japanese)

Tanida, K. (1986) A revision of Japanese species of the genus Hydropsyche (Trichoptera, Hydropsychidae) I. Kontyú, 54, 467-484.

Tanida, K., Nozaki, T., Ito, T. \& Hattori, T. (2005) Trichoptera. In: Kawai, T. \& Tanida, K. (Eds.), Aquatic insects of Japan: Manual with keys and illustrations, Tokai University Press, Kanagawa, pp. 397-572. (in Japanese)

Townsend, C.R. (1989) The patch dynamics concept of stream community ecology. Journal of the North American Benthological Society, 8, 36-50.

Wallace, J.B. (1990) Recovery of lotic macroinvertebrate communities from disturbance. Environmental Management, 14, 605-620.

Wiggins, G.B. (1996) Larvae of the North American caddisfly genera (Trichoptera). Second Edition. University of Toronto Press, Toronto, $457 \mathrm{pp}$.

Wiggins, G.B. \& Currie, D.C. (2008) Trichoptera Families. In: Merritt, R.W., Cummins, K.W. \& Berg, M.B. (Eds.), An Introduction to the Aquatic Insects of North America, Fourth Edition. Kendall/Hunt, Iowa, pp. 439-480. 